\title{
MIR1208 Gene
}

National Cancer Institute

\section{Source}

National Cancer Institute. MIR1208 Gene. NCI Thesaurus. Code C118127.

This gene may play a role in the modulation of transcription. 